ACTA UNIVERSITATIS LODZIENSIS

FOLIA LITTERARIA POLONICA 8(38) 2016

http://dx.doi.org/10.18778/1505-9057.38.10

Maria Judyta Woźniak*

\title{
In the Forest of Words I Got Lost - About the Silence in the Poetry of Antonio Colinas and Zbigniew Herbert
}

The spiritual and intellectual community of Antonio Colinas and Zbigniew Herbert is mainly visible in the search for harmony, which is present in their poetry. Its need, dictated by a desire to find order and meaning, manifests clearly in a poetic conception of visual arts, music, and poetry ${ }^{1}$. A special area of research is silence, possibly always accompanying the art of word.

Although the poets are separated by a whole generation and geographical distance, and in their poetry there is a lack of common influences, their literary output reveals many ties. Antonio Colinas (b. 1946) and Zbigniew Herbert (1924-1998) are poets, prose writers and translators belonging to, in a broad sense, contemporaneity, many time recipients of prestigious prizes. They both wrote in times when one searched new forms of the poetical expression, "new enunciation" - Colinas towards former "Social poetry"2, Herbert in the post-WWII years of crystallizing a new poetic language. Quite often critics combined their poetry with the ambiguous term of classicism ${ }^{3}$, first of all because of a profound connection with Mediterranean culture, especially antiquity ${ }^{4}$. The connection between

* Ph.D., Uniwersity of Łódź, Faculty of Philology, Department of Spanish Philology; e-mail: judytawo@gmail.com.

${ }^{1}$ See unpublished doctoral thesis of the author, $W$ poszukiwaniu harmonii istnienia. Studium porównawcze poezji Antonia Colinasa i Zbigniewa Herberta, Warsaw 2013.

2 The poet is frequently classified by the critics as the so-called „Newest Ones”, poets born in years 1939-1953, known also as the 1970 Generation or "venecianos" (besides such poets as for example Pere Gimferre, Guillermo Carnero), who opposed political and social functions of literature and requirements towards the language to be clear and transparent.

${ }^{3}$ Herbert himself gave permission for that notion, when he said: "Now, I am looking for my own, imaginary formula of classicity of poetry, which would have a chance to survive". Z. Herbert, J. Zawieyski Korespondencja 1949-1967, P. Kądziela (ed.), Biblioteka "Więzi", Warsaw 2002, p. 41. See also: L.M. Alonso Gutiérrez, Antonio Colinas: un clásico del siglo XXI, Universidad de León 2000.

${ }^{4}$ Such a definition of the intelectual-spiritual community of both poets describes the character of the comparative methods which I have assumed. As Teresa Kostkiewiczowa noticed, this type of attitude is closer to the contemporary methodology: "it is irrelevant whether there are actual contacts and relations between the examined works or literary constructs, but what is important 
this work and antiquity can be seen especially in attempts to regain belief in ancient harmony of the world, which meant order and sense - of faith presented in our culture at least from Pythagoreans. The poet is given hope for order and sense by a thought that he can express which he wants. These searches of the most proper form of expression led Colinas and Herbert towards silence, which paradoxically inspires to taking new "attempts of description".

The poetry of both authors reminds that words have lost the connection with the entirety of sense, that they stopped to mean or communicate something and last. As Herbert noticed in a poetic prose work entitled Episode in a library (Hermes, dog and star), the destruction of the word is absolute: "there is no limit to decay". The heart of the matter gets out of metaphorical "inscriptions" - of poetry. Herbert's Curatia Dionisia, a poem from the collection with a metapoetic title Inscription, shows thata symbolic description of a tombstone cannot tell much about the dead woman Convention proves to be unfit to the diversity of life:

[...] Napis (skażona łacina)

głosi że Curatia Dionisia żyła lat czterdzieści

i własnym sumptem wystawiła ten skromny pomniczek ${ }^{5}$

[The inscription (corrupt latin)

proclaims that Curatia Dionisia lived forty years

and at her own expense had raised this modest little monument]

(transl. A. Czerniawski)

That is what the inscription on the tombstone of the courtesan said. A woman's life, her occupation, relations with others, changing fortunes, and most of all - solitude and sorrow remained unexpressed, clear only with the order of silence, despite the words:

Samotny trwa jej bankiet Zatrzymany puchar

Twarz bez uśmiechu Za ciężkie gołębie ${ }^{6}$

[Lonely is her banquet The cup half-drained

Unsmiling face Doves too ponderous]

(transl. A. Czerniawski)

are the similarities, that is parallels, homologies, concurrences, analogies, synchronisms, etc.". T. Kostkiewiczowa, Komparatystyka literacka - zakres i treść pojęcia. Status naukowy badań porównawczych. Tradycja i współczesność, in: Badania porównawcze. Dyskusja o metodzie. Radziejowice 6-8 lutego 1997 r., A. Nowicka-Jeżowa (ed.), Świat Literacki, Izabelin 1998, p. 14.

${ }^{5}$ Z. Herbert, Wiersze zebrane, R. Krynicki (ed.), Wydawnictwo a5, Cracow 2008, p. 347.

${ }^{6}$ Ibidem. 
Colinas described a very similar experience, although instead of ancient references he used contemporary reality. One of the Catorce retratos de mujer ( $E l$ laberinto invisible) shows Soraya, a well-known singer, whom the poetic subject met on a plane. Today's language of everyday communication is a contemporary equivalent of ancient "corrupted Latin". Those who in search of information on the extraordinary passenger will look at websites will only find morsels of information, trivial clichés.The object of individual experience must remain incommunicable, also in poetry, which verses seem to resemble this helpless language of everyday life:

También yo he intentado buscar en la pantalla, pero allí no encontré ni sus dos ojos verdes, ni su vestido azul, ni sus piernas tan blancas.

[Ja też próbowałem szukać na ekranie, ale nie znalazłem ani jej zielonych oczu, ani niebieskiej sukienki, ani bardzo białych nóg. $]^{\top}$

[I have tried to look for her on the screen, but I did not find it neither her green eyes neither blue dress nor very white legs.]

A poet cannot talk in such an orderly and significant way, how he would want and need to, because "words dropped out of a whole" / "słowa wypadły z całości", as Herbert says ([We fall asleep on words...] from the collection Inscription).

Even if it seems that a word has fulfilled its communicative function, that it reached the Other, it might not be understood - he will deform it, change "into lines, accents, caesuras", which will become at the most the object of a soulless, "academic" analysis (poetic prose Episode in a library from the Hermes, dog and star collection). Thus people's experiences marked with personal drama must melt in non-communicativeness: "Lament of the fallen poet now looks

${ }^{7}$ A. Colinas, Obra poética completa (1967-2010), Ediciones Siruela, Madrid 2011, p. 892. Transl. of Spanish quotations - M.J.W. The aim of the translation is to show the most important meanings of the original regarding the comparative character of the work, whereas the redaction of literary translation doesn't. 
like a salamander eaten by ants" / "Lament poległego poety wygląda teraz jak salamandra objedzona przez mrówki" - Herbert commented ironically on such analytic practices. The results of a "correctly" conducted analysis, according to all the principles of its "art", the poet juxtaposed with a different image - which gave rise to the work read by the protagonist:

Kiedy nieśliśmy go pod ostrzałem, wierzyłem, że jego ciepłe jeszcze ciało zmartwychwstanie w słowie. Teraz, kiedy widzę śmierć słów, wiem, że nie ma granicy rozkładu. Pozostaną po nas w czarnej ziemi rozrzucone głoski. Akcenty nad nicością i prochem. ${ }^{9}$

[When we carried him off under fire, I believed his still warm body would be resurrected in the work. Now I see words dying, I know that there is no limit to decay. What will remain after us are fragments of words scattered on the black earth. Accent signs over nothingness and ash.]

The point is not just that the poet will miss an eternal monument of words and he will not be consoled by "exegi monumentum..." "The death of words" has much more serious consequences because it does not allow the strengthening of individual human experiences. There is no "resurrection in a word", that is salvation through art does not exist ${ }^{10}$. „Koniec koniec / nie udało się / wniebowstąpienie" ( "Enough enough / the ascension / failed") - with a colloquial expression Herbert summed up the efforts of the poet in the poem Writing (Study of the Object). Death of words, of the last hope is the most imaginable misfortune. If that what "lasts has been established by poets", and they do not have anything to create of - nothing can give any constant support in a changeable and confused world. An interesting commentary is Colinas' remark on Ruysbroeck's thought. The Spanish poet paid attention to the connection between word and death:

[...] zaciśnij usta, zachowaj w sobie harmonię, żeby nigdy nie przyszła śmierć. Ale jak zamilknąć? Słowo i śmierć są współistotne z człowiekiem”’11.

["set your mouth, keep harmony in yourself in order to death never come. But how to be silent? Word and death are consubstantial with human"]

Silence as an act of giving up words would protect from death connected with them, as words cannot express the essence of the experience:

${ }^{8}$ Z. Herbert, Wiersze..., p. 179.

${ }^{9}$ Ibidem.

${ }^{10}$ P. Śliwiński wrote about that, Poezja, czyli bunt, w: Poznawanie Herberta 2, Selection and Introduction A. Franaszek, Wydawnictwo Literackie, Cracow 2000, p. 160.

${ }^{11}$ A. Colinas, Tres tratados de armonía, Tusquets, Barcelona 2010, p. 170 
¿Cómo hacer duradera con los versos

la impresión absoluta?

¿Cómo testimoniar sobre lo que soñamos

durante una vida y, por sorpresa,

sale a nuestro encuentro

inesperadamente?

[Jak utrwalić w wierszu

wrażenie absolutne?

Jak świadczyć o tym, co śnimy

w życiu i co zaskakuje,

wychodzi na nasze spotkanie

niespodziewanie?]

Motivo para una "Vita Nuova" (Astrolabio) ${ }^{12}$

[How to preserve in a poem

absolute imression?

How to be a sign of which we dream

in life and what surprises,

comes out to our meeting

unexpectedly?]

The questions remain rhetorical, of course.

In multitude of words harmony is lost, i.e. the feeling of order and sense: "In the forest of words I got lost" said the poetic subject of Colinas' poem La muerte de Armonía. Silence to be the means of rescue from being lost in words, their helplessness and importunity. The poetic subject in the poem by Herbert Mr. Cogito's Eschatological Premonitions (Report From A Besieged City) thinks without any grief about death, which will deprive him one day of the joy of music, leaving silence:

na stole komisji werbunkowej

złoży płatki uszu

w doczesnym życiu

był melomanem ciszy ${ }^{13}$

[on the recruiting commission's desk

he will lay out the petals of his ears

\footnotetext{
12 Idem, Obra..., p. 326.

13 Z. Herbert, Wiersze..., p. 474.
} 
in his temporal existence

he was a lover of silence]

Obviously Herbert never sought out the lack and emptiness just for them, but his affection towards silence reminds meditational abjuration of sensual reality in order to reach its deeper layers. It is about such an experience of the depth which requires

wyłączenia zmysłów, wyciszenia wnętrza - paradoksalnego usłyszenia prawdziwej ciszy, która jest znakiem wykroczenia poza granice doczesności ${ }^{14}$.

[disconnecting senses, softening inner feelings - a paradoxical hearing of real silence, which is a sign of going beyond the limits of mortal life]

This is what Colinas wrote about a word which leads to silence in a study of Antonio Machado's poetry:

Orfeusz, który "sprawia, że rozbrzmiewa harmonia" i który, dzięki temu, przywraca wartość słowu. Przywraca mu wartość czy mu ją odbiera? [...] słowo pokazuje tylko jedną stronę rzeczywistości. Tak samo jak góra lodowa, która skrywa większość swojej masy, słowo skrywa swoje ostateczne znaczenie. U prawdziwego poety słowo jest $[\ldots]$ "prasłowem". A ono twórczą ciszą. ${ }^{15}$

[Orpheus, who "makes that harmony resound" and who, thanks to it, restores the value of the word. He restores its value or does he take it away? [...] the word shows only one side of reality. As an iceberg which hides the majority of its mass, the word hides its final meaning. For a real poet the word is [...] a "great-word". And it is a creative silence.]

A writing poet is always accompanied by the torment of inexpressiveness, coming from incongruity of words towards that which they try to express ${ }^{16}$. Silence does not replace the word but it itself is which the word cannot express.

\footnotetext{
${ }^{14}$ Poetry and silence, music and silence - are inseparable. Paul Evdokimov, an Orthodox theologian, noticed this double unity of word and silence in a broader context, referring it to the profound spheres of human cognition: "Every catafatical cognition, positive, demands apophasis, limit, where it would stop at the threshold of which is inexpressible and find the end in the system of contemplated symbols [...]". P. Evdokimov, Sztuka ikony. Teologia piękna, transl. M. Żurowska, Wydawnictwo Księży Marianów, Warsaw 2003, p. 20.

${ }^{15}$ A. Colinas, Una visión totalizadora de Antonio Machado, "El País / Libros", 27 January 1985, p. 4.

${ }^{16}$ Herbert declared himself in favour of poetry which appreciates silence, as the poets of silence close to him - Friedrich Hölderlin, Paul Celan, Tadeusz Różewicz, and, obviously, Rainer Maria Rilke and Thomas Stearns Eliot, mentioned in the poem To Ryszard Krynicki-letter.
} 
Harmonia, Colinas' protagonist (La muerte de Armonía), expresses this difficult ambiguity in a peculiar declaration:

Palabra es una sombra y una luz.

Me dio sed la palabra y me sacié.

En bosque de palabras me he perdido.

[Słowo jest cieniem i światłem,

Słowo napełniło mnie pragnieniem i nasyciłam się.

W lesie słów się zgubiłam]

[Word is a shadow and a light,

Word made me thirsty and I was satisfied.

In the forest of words I got lost $]^{17}$

The word of the poet is both shadow and light, it is as a "remnant of light" from a poem by Colinas (,escoria de la luz", Post-scriptum, from the Noche más allá de la noche collection). As light disperses the darkness, silence melts the remains of words incongruent to the reality:

Pero fue el silencio quien venció a la luz.

Un gran silencio ahogó todas las sensaciones.

Cabo de Berbería (Astrolabio $)^{18}$

[Ale to cisza pokonała światło.

Wielka cisza zagarnęła wszystkie doznania.]

[But it was silence which defeated the light, Great silence appropriated all the sensations.]

The whole meaning of the poetic word will shine not until in the silence, and in this way "content will be completed" / "treść się dopełni", as Herbert writes in the poem [We fall asleep on words...] from the collection of poem Inscription:

trzeba śnić cierpliwie

w nadziei że treść się dopełni

że brakujące słowa

wejdą w kalekie zdania

\footnotetext{
${ }^{17}$ A. Colinas, Obra ..., p. 541

${ }^{18}$ Ibidem, p. 349.
} 
i pewność na którą czekamy

zarzuci kotwicę ${ }^{19}$

[you must dream patiently

hoping the content will be completed

that the missing words

enter crippled sentences

and the certainty we are waiting for

casts anchor]

The lack of the word restoring coherence, meaning and harmony cripples. All that remains is hope for certainty - there is no certainty because the essence of life is still a fragment, a harmony, "we are waiting for", in the present unreachable. With such hope the poet continued patiently to compose poems ${ }^{20}$, looking for harmony between the word and silence.

Through silence one can only express some meanings. Those experiences which one cannot grasp neither in words nor silence, are lost into unexpressiveness:

Nikomu nie przekażesz wiedzy

twój tylko słuch jest i twój dotyk

na nowo każdy musi stworzyć

swą nieskończoność i początek

Kłopoty matego stwórcy (Struna światła) $)^{21}$

[You cannot pass on the knowledge yours is the ear and yours the touch each of us must build from scratch his own infinity his own beginning]

Troubles of a minor creator (Chord of Light)

The problem is that the available forms of expression refer to similar feelings of many people, and they cannot meet the poetic needs of individuality. And yet poetry exists. In fact Colinas wrote his poem, though he thought that strengthen-

${ }^{19}$ Z. Herbert, Wiersze..., p. 358.

${ }^{20}$ Aleksander Fiut wrote about this topic, perhaps too assertively ascribing religious references to Herbert: "Words of complementing content and 'certainty we are waiting for' seem to show that in Herbert's poetry - just as in Miłosz's poetry - was fitted into a project of the Book, the Final Text, which author, guarantor and at the same time real meaning is God himself ". A. Fiut, Język wiary i niewiary, w: Poznawanie Herberta, A. Franaszek (ed.), Wydawnictwo Literackie, Cracow 2000 , p. 268.

${ }^{21}$ Z. Herbert, Wiersze..., p. 52. 
ing "an absolute feeling" is impossible. Herbert acted similarly as he not only "would like to write a poem about a pink ear", but simply he wrote the poem, even if it did not represent reality. The essence of poetry is a paradox: it exists, although it should not. "It must be a daily routine," Herbert argued, "an article of prime necessity. [...] it is a human arch-human function," 22 .

The attempts of writing, in advanced doomed to fail, are raised in Herbert's poem I would like to describe (Hermes, dog and star). "Light which is being born in me" he alone can try to describe. He made that attempt by negation, an apophatic method explaining which is not his interior light known only to him. The essence of the matters immersed in silence must be silent:

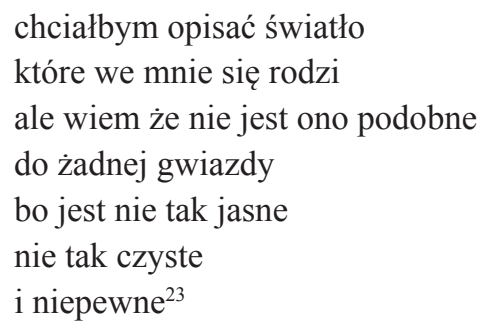

[I would like to describe a light which is being born in me but I know it does not resemble any star for it is not so bright not so pure and is uncertain]

(transl. Alissa Valles)

The "incessant bustling of the poet" ( $A$ Tale from the collection Hermes, dog and star) consists of a continuous repeating of an "attempt to describe" on the broadline of silence. It is not surprising that one of the poems from Study of the Object, a collection abounding in metapoetic considerations, Herbert entitled as: Attempt at a description. It should be admitted that at the beginning the poet has maximizing intentions, although he shows them not without irony:

naprzód opiszę siebie

zaczynając od głowy

\footnotetext{
${ }^{22}$ Idem, Poezja w próżni, “Tygodnik Wybrzeża” 1948, no 38, p. 3.

${ }^{23}$ Idem, Wiersze..., p. 86.
} 
[First I will describe myself

starting from my head]

Gradually creative aspirations are decreasing...:

albo lepiej od nogi

albo od ręki

od małego palca lewej ręki ${ }^{24}$

[or better from my foot

or from my hand

from the little finger of my left hand]

(transl. Alissa Valles)

... to finally become stuck in fruitless efforts of calling a small part of the body. Despite general epithets ("peculiar", "only") no word can describe a concrete finger. In the attempts at describing, principium individuationis is lost because existing words correspond to many "examples" of "a left hand's little finger". The uniqueness of his finger evades verbalisation, remaining a matter of inexpressible and non-transferable experience:

jest to osobliwy palec

jedyny na świecie mały palec lewej ręki

dany mi bezpośrednio ${ }^{25}$

[it is a peculiar finger

a left hand's little finger unique in the whole world

given to me directly]

(transl. Alissa Valles)

The point is that everybody could describe their little finger that way. Nevertheless, Herbert dreamt about a language which could express the inexpressible. This is a fragment of the poem Dream Language (Epilogue to a Storm):

ale taki powinien być

język snu

język piękny dalekosiężny

zwiewny

\footnotetext{
${ }^{24}$ Z. Herbert, Wiersze..., p.279.

${ }^{25}$ Ibidem.
} 
gdy porzuca gramatykę

zasady fonetyki

$[\ldots]$

język którego nie znam ${ }^{26}$

[but that is what

dream language

should be like

a fine language

with a long arm

airy

it flouts grammar

phonetics principles

[...]

a language I don't know]

The poetic expression does not have at its disposal any language, as the poet envisaged it. The poet speaks only in a way restrained with conventional principles- not only in the field of grammar and phonetics. "A fine language / with a long arm" is an unavailable and unrecognizable language.

¿Dónde econtrar palabras para escribir tu historia?

¿Con qué alucinaciones construiré mis versos?

Diosa o mujer, te miro y te pierdo para siempre. ${ }^{27}$

[Where could I find words to write your story?

Which illusions should I build my verses of?

Goddess or a woman, I look at you and I lose you forever]

- wrote the Spanish poet in an early collection of poems entitled Truenos y flautas en un templo in the poem Ocaso.

The poet, helpless towards that which continues to remain inexpressible, must pull back under the "perennial inability of all the poets to express", agree on "the richness of feelings and the shortage of what remains on the paper", as Colinas said ${ }^{28}$. Since poetic works cannot forswear their paradoxical existence, remain doomed to fruitless efforts of expressing the meaning, always bringing a sense of unfulfillment and failing the task.

\footnotetext{
${ }^{26}$ Idem, Wiersze..., pp. 648-649.

27 A. Colinas, Obra..., p. 136.

${ }^{28}$ Idem, El primer Aleixandre, "Ínsula" 1973, issue 316, p. 3.
} 
The presented searches for the proper form of expression, between the word and silence, show the same way of two poets from different corners of Europe. Both Colinas and Herbert had the experience of insufficiency of words, hope connected with the sphere of silence in poetry and the search of language which could fulfil the poet's needs. Obviously there are no easy answers nor ideal solutions. In the case of inadequacy of words and silence what remains is "attempts at describing", helpless searches for a language appropriate for poetry. When wrestling with its doubts, poetry one more time shows its paradoxical nature: it exists, although it can never express the essence of human experience. Colinas and Herbert gave their accounts of unavoidable aporia of their own art. And despite it they wrote.

\section{Bibliography}

Alonso Gutiérrez Luis Miguel, Antonio Colinas: un clásico del siglo XXI, Universidad de León 2000.

Colinas Antonio, Obra poética completa (1967-2010), Ediciones Siruela, Madrid 2011.

El primer Aleixandre, "Ínsula" 1973, issue 316, p. 3.

Tres tratados de armonía, Maginales Tusquets, Barcelona 2010.

Una visión totalizadora de Antonio Machado, "El País / Libros”, 27 January 1985, p. 4.

Evdokimov Paul, Sztuka ikony. Teologia piękna, transl. M. Żurowska, Wydawnictwo Księży Marianów, Warsaw 2003.

Fiut Aleksander, Języ wiary i niewiary, in: Poznawanie Herberta, A. Franaszek (ed.), Wydawnictwo Literackie, Cracow 2000, pp. 264-279.

Herbert Zbigniew, Poezja w próżni, “Tygodnik Wybrzeża” 1948, issue 38, pp. 3-5.

Wiersze zebrane, R. Krynicki (ed.), Wydawnictwo a5, Cracow 2008.

Herbert Zbigniew, Zawieyski Jerzy, Korespondencja 1949-1967, P. Kądziela (ed.), Biblioteka "Więzi", Warsaw 2002.

Kostkiewiczowa Teresa, Komparatystyka literacka-zakres i treść pojęcia. Status naukowy badań porównawczych, w: Badania porównawcze. Dyskusja o metodzie. Radziejowice 6-8 lutego 1997 r., A. Nowicka-Jeżowa (ed.), Świat Literacki, Izabelin 1998, pp. 11-16.

Śliwiński Piotr, Poezja, czyli bunt, in: Poznawanie Herberta 2, selection and introduction A. Franaszek, Wydawnictwo Literackie, Cracow 2000, pp. 149-166. 
Maria Judyta Woźniak

\title{
In the Forest of Words I Got Lost - About the Silence in the Poetry of Antonio Colinas and Zbigniew Herbert
}

\author{
(Summary)
}

The aim of this comparative article is to present the similarity of the poetic concepts of Antonio Colinas and Zbigniew Herbert. The poets did not know each other, there are no traces of mutual influences to be found in their poetic output either, however, they both seemed to be equally connected with the Mediterranean culture. This article concentrates on the meaning of silence in their poetry seen as a necessary supplement to the art of words, hope for saving the sense from ambiguity and hubbub of words. The insufficiency of both the accessible language and silence inspired the poets to seek a form of expression that could satisfy human needs, "the unattainable language." The search, between the word and silence, is manifested in the poetic works of Colinas and Herbert.

Keywords: Antonio Colinas; Zbigniew Herbert; contemporary poetry; comparative literature; silence 